\title{
Social Values and the Yahooboys' Subculture in Nigeria: Towards A Paradigm Shift for National Value Re- Orientation
}

\author{
Philip Nnameziri Ndubueze \\ Department of Sociology and Anthropology \\ University of Nigeria, Nsukka \\ Enugu State, Nigeria \\ philipndubueze@yahoo.com
}

DOI: $10.36108 / \mathrm{NJSA} / 3102 / 11(0180)$

\begin{abstract}
Society creates perimeters within which its members are expected to operate and employ sanction to stimulate, reinforce and dissuade certain behaviours. Social values generally define what society considers appropriate, right, noble or worthy behaviour. They drive the goals individuals set for themselves. However, when societal values are built on wrong principles or are clearly inconsistent, members' goals become illfocused .This paper attempts to clarify some conceptual issues on social values, and traces the problem of online advance fee fraud, otherwise called yahoo-yahoo, among Nigerian youths to Nigeria values crisis and inconsistency. It sees this crisis as permeating every stratum of the Nigerian society and argues that a society that celebrates wealth, regardless of its source will produce a generation of youths who will in their pursuit of wealth indulge in all kinds of social vices, including cyber crime and criminality. It considers values re-orientation a panacea for cyber crime control.
\end{abstract}

Keywords: cyber crime, social values, yahoo-yahoo, advanced fee fraud, youth

\section{Introduction}

Ideally, society defines what constitutes appropriate behaviour and expect all members to operate within the confines of that definition. But society rarely achieves full and total compliance. Expectedly, some members of society, acting individually or as a group, seek ways to circumvent and compromise those definitions. Durkheim (cited in Swingewood, 1991: 233) observes that although social institutions will tend towards equilibrium among its component parts, elements of 'mal-integration' will remain, thus necessitating social control systems. From birth to death the individual is checked by all kinds of rules that limit their likely course of action (Friedman and Hechter, 1988); these rules find expression in values and are regarded as legitimate and binding (Hogan, 2006). Values creates space within which members of society are to operate and delineates boundary lines which when crossed is considered deviance. Earlier, Rose (1983: 174) defines deviance as "behaviour that does not conform to social expectations."

According to Briggs (2012: 16), "Nigeria at Independence in 1960 consisted of proud hardworking people with sound moral values"; thus the emergence of the yahoo-yahoo subculture in Nigeria is fundamentally 
antithetical to the sound moral values that Nigerians were famous for at Independence. It is the objective of this paper to x-ray the extent of moral decadence in modern Nigerian society, and the extent to which this has impacted her social values as well as how this scenario has given rise to online advance fee fraud.

E-fraud is on the increase the world over. The Internet Crime Compliant Centre (IC3, 2010) report ranked Advance Fee Fraud as the sixth most reported offense in the world. Similarly, it ranked Nigeria third on the roll of the top 10 cyber crime perpetrator countries of the world (IC3, 2011). In 2007, IC3 sent a complaint to the U.S National Aeronautics and Space Administration (NASA) office, the Inspector General Computer Crimes Division, about one Ayodele Saliu, who was involved in "419" (advance fee fraud) Nigerian schemes, phishing, bank fraud and credit card fraud. IC3 search of names and email address associated with the offender revealed 21 complaints and reported losses of over $\$ 10,000$. He was indicted in 2012, and was wanted in the United States for 11 cases which included charges of wire fraud, bank fraud, computer intrusion, and identity theft. The schemes reportedly had victim-losses of over $\$ 500,000$ (IC3, 2012). In July 2007, IC3 got complaints from a U.S. law firm that they were contacted through email asking them to assist in a petty debt collection. The alleged debtors sent the victims cheques and instructed them to transfer the funds collected on their behalf after deducting their consultancy fees. The funds were for the most part, wired to banks in Korea, China, Ireland and Canada. However, it turned out that all the cheques were fake (IC3, 2012).

In 2012, the Internet Crime Compliant Centre (IC3) received 289,874 consumer- complaints, with a loss of $\$ 525,441,110$. This represented 8.3 percent increase in reported losses from the previous year. The topmost victim complaint-country was the United States $(91.2 \%)$. The most frequently reported cyber crimes were: auto fraud, FBI impersonation e-mail scam, intimidation/exploitation scam, scare ware/ransom ware, real estate fraud and romance scam (IC3, 2013).

This paper examines the nexus between the decline of the traditional Nigeria value system and the emergence of cyber crime particularly, online Advance Fee Fraud popularly known as yahoo-yahoo in contemporary Nigeria. The paper argues that yahoo-yahoo is a consequence of the over-emphasis on wealth acquisition by the Nigerian society and a symptom of a shaky or failed value system. It calls for a paradigm shift for national value re-orientation and sees a broad-based value reorientation programme as key in the efforts towards national value re-engineering and re-definition.

Modern Nigeria is plagued by a value crisis that is fast eroding her traditional value system. The growth of Information and Communication Technology (ICT) system in Nigeria in the past one decade or so has created a new form of crime and criminality. The "Generation Y" (otherwise called "millennials"), a term used in literature to describe those who are born between the 1980s and 2000s, (see Huntley, 2006; Twenge, 2012; Horovitz, 2012; Ndubueze, 2013) are technology/internet savvy and social media oriented. 
Today, internet traffic across the globe is generation y-heavy. From this group has emerged a deviant subculture known as yahoo-yahoo boys in Nigeria. They seem not to be properly integrated into Nigeria's traditional values and have embraced a world view that is pro-quick fix, pro'-short-cuts and wealth crazy. This has culminated into ambivalence for "hot cash" and the use of the internet infrastructure to pursue this illegitimate goal. These young Nigerians need to make a definite shift from criminality to conformity, but this shift will not happen until a major shift has taken place in the social system that gave rise to their antisocial behaviour in the first place.

\section{Theoretical Framework}

Merton's Anomie (Strain) Theory and Jaishankar's Space Transition model will form the theoretical orientation of this paper. They are useful in explaining the problem of cyber crime and particularly yahooboyism in Nigeria.

\section{Merton's Anomie (Strain) Theory}

Merton (1938) argued that a major contradiction existed between cultural goals and the social structure in the United States. Borrowing from Durkheim, he called this contradiction 'anomie', which basically refers to a state of normlessness. He points out that in the U.S., the cultural goal of achieving wealth is considered possible for all citizens, although the social structure places limits to the legitimate "institutionalized means" available for obtaining the goal. Thus, a strain is placed on people (Bohm \& Haley, 2005).

Merton explained why people accept or reject society's goals, the socially approved means of fulfilling their aspirations, or both. He proposed five basic forms of adaptation. These include conformity to social norms which involves acceptance of both societal goal and approved means. The other four types of behaviour involve some kind of deviance. "Innovators" accept societal goals but they pursue them through unacceptable means. "Ritualists" abandon the goal but stick to the institutional means. "Retreatists" withdraw from both the goals and the means, while "Rebels" feel that they are alienated from societal means and goals, and may seek a completely different social order (Schaeffer, 2003).

Merton's strain theory has some relevance to the problem of cyber crime in Nigeria. The Nigerian society values success often measured by wealth acquisition. However, due to high rate of unemployment, the teeming Nigerian youth are unable to access the legitimate means of acquiring wealth. Some of these youth are eventually lured to cyber crime by their deviant peers who promise them huge gains and less pains. Merton's theory can explain some behaviours, such as illegal gambling by the disadvantaged (Clinnard \& Miller, 1998). But Schaeffer (2003) criticizes Merton for making little effort to establish the extent to which his five models account for all types of deviance. 


\section{Space Transition Model}

The Space Transition Model, which is the first cyber crime specific model, was developed by one of the founding fathers of cyber criminology (Jaishankar, 2007). Jaishankar explains the nature of people who exhibit their conforming and non-conforming behaviour in the physical space and cyber space. Space transition involves the movement of persons from one space to another (example, from physical space to cyberspace and vice versa). Space transition model argues that people behave differently when they move from one space to another. Below are the assumptions of the model:

i. Persons with pent-up criminal behaviour (in the physical space) have a propensity to commit crime in the virtual world, which, otherwise they would not commit in the physical space, due to their status and position.

ii. The ability to switch identity, dissociative anonymity and lack of deterrence factor in the cyberspace incentivize cyber crime.

iii. People's criminal behaviour in the cyberspace is likely to be imported to the physical space and their criminal behaviour in the physical space may be exported to the cyberspace as well.

iv. Offenders capability to $\log$ in and $\log$ out on the cyberspace and the dynamic spatio-temporal nature of cyberspace makes escape easy.

v. (a) Strangers are likely to unite together in the cyberspace to commit crime in the physical space.

(b) Associates in the physical space are likely to unite to commit crime in the cyberspace.

vi. Persons from closed society are more likely to commit crimes in cyberspace than persons from open society.

vii. The conflict of norms and values of the physical space with those of the cyberspace may lead to cyber crimes (Jaishankar, 2007; Jaishankar, 2008).

The Space Transition model which is one of the newest criminological models that seeks to explain crime and deviance, has not been subjected to rigorous empirical testing. However, Jaishankar's model represents the first ever attempt to develop a cyber crime-specific model in the explanation of cyber criminality and deviance.

\section{Methodology}

The method used in this research is content analysis. The content of relevant and allied literature on social values and cyber crime in Nigeria are reviewed. Cyber criminology is still novel and emerging in Nigeria. There is dearth of scientific and documented works on the subject; however, every effort is made to review relevant and available data and to connect them to the current discourse. Furthermore, literature on cyber criminality and e-fraud across cultures and countries are reviewed. Some empirical studies and statistical data from different countries are also reviewed, albeit briefly in order to enable the 
audience appreciate the current scenario of value crisis and cyber criminality in other regions.

\section{Understanding Cyber Crime and Dynamics of the Yahooboys' Portfolio}

The modern society is bedevilled by the growing sophistication of crime (Ndubueze, 2008), culminating into the export of most traditional crimes from the physical (real world) space to the cyber (virtual) space. The physical space is characterized by perimeter fences, surveillance cameras, security dogs and highly policed borders. Conversely, the cyber space is relatively borderless and open, allowing for free flow of virtual traffic. Unfortunately, criminal elements now exploit the vulnerability of computer systems and networks to carry out a wide range of criminal activities online.

Cyber crime is one of the startling consequences of a digitalized world. It is a continuing global social problem and will continue to agitate and engage the minds of all stakeholders. "Cyber crime is emerging as a major International Criminological issue" (Roberts, 2008: 1). It generally refers to the use of computer in carrying out illegal activity (Jewkesy, 2003), and is perpetrated on the internet with the use of computer as either a tool or a target (Joseph, 2006). However, not all crimes involving the use of computer can be termed cyber crime. For example if a computer is stolen or used in hitting someone, clearly a computer was the target and was used in committing crime but obviously, these cases cannot be described as cyber crime. To pass as cyber crime, therefore, the crime must have a link to the cyber space. The internet architecture must have directly or indirectly facilitated its commission.

The yahooboys comprising those born between the 1980s and 2000s, often referred to as "Generation Y" constitute a deviant subculture in contemporary Nigeria. They are made up of mainly young school leavers and undergraduates. They are technology savvy and love smart electronic gadget. They are pathological internet addicts and particularly obsessed with the social media. They live extravagant lifestyle and hang out in clubs. They are usually funseekers and chronic adventurers. They belong to two categories of cyber cafe users that have been described as deviant routine users and deviant Very Important (VIP) users (see Ndubueze, 2013).

\section{Social Values and Cyber Criminality in Nigeria}

Values are considered legitimate and binding. They set standard through which the ends of actions are selected (Hogan, 2006). Values may be viewed as higher order norms (Johnson as cited in Rao, 2012) and may conflict with one another (Rao, 2012). The traditional Nigerian society saw the codification of a set of national values that are oriented towards very high moral standards and ethics. A good name was a virtue so highly esteemed that it would not be traded for money or any other commodity of mundane value. People who demonstrated the best examples of integrity, modesty, service and probity were 
celebrated by society. Unfortunately, this whole scenario has changed in modern Nigeria society. The once cherished traditional values are now been compromised. The table below attempts to capture this shift from traditional values to modern value, and highlights the consequences of that transition.

Table 1: Nigerian Value (National Character) Index: Traditional Versus Modern, and Consequences of the Value Shift

\begin{tabular}{|c|c|c|c|}
\hline Institution & $\begin{array}{c}\text { Traditional } \\
\text { character } \\
\text { (Expressed Values) }\end{array}$ & $\begin{array}{l}\text { Modern character } \\
\text { (Implied Values) }\end{array}$ & $\begin{array}{c}\text { Outcome/ } \\
\text { Consequence }\end{array}$ \\
\hline Family & $\begin{array}{l}\text { Lead agent of } \\
\text { socialization. Active } \\
\text { in impartation of } \\
\text { social values (e.g. } \\
\text { obedience, honesty, } \\
\text { hard work, respect } \\
\text { for elders etc.) }\end{array}$ & $\begin{array}{l}\text { Weak agent of } \\
\text { socialization. Parents } \\
\text { now active in the work } \\
\text { force, leave this } \\
\text { primary responsibility } \\
\text { to third parties (e.g. } \\
\text { baby-sitters, nannies } \\
\text { and schools). }\end{array}$ & $\begin{array}{l}\text { Mal-adjusted children } \\
\text { who drift into delin- } \\
\text { quency and crime in } \\
\text { early adulthood. }\end{array}$ \\
\hline Education & $\begin{array}{l}\text { High academic stan- } \\
\text { dard. Job placement } \\
\text { tied to academic } \\
\text { achievement/skills. }\end{array}$ & $\begin{array}{l}\text { Falling standards. Job } \\
\text { placement now in- } \\
\text { fluenced by parochial, } \\
\text { ethnic, nepotic and } \\
\text { religious } \\
\text { considerations. }\end{array}$ & $\begin{array}{l}\text { Academic corruption } \\
\text { at all levels, espe- } \\
\text { cially secondary and } \\
\text { tertiary levels. Low } \\
\text { productivity. Brain } \\
\text { drain syndrome: peo- } \\
\text { ple migrate to the } \\
\text { West in search of } \\
\text { greener pastures. }\end{array}$ \\
\hline Polit & $\begin{array}{l}\text { Platform for service. } \\
\text { Issue based campai- } \\
\text { gns, sound political } \\
\text { ideology and party } \\
\text { manifestoes. Fairly } \\
\text { free and fair election. }\end{array}$ & $\begin{array}{l}\text { Platform for personal } \\
\text { enrichment } \\
\text { aggrandizement. 'Do } \\
\text { or die affair" Winner- } \\
\text { take-all syndrome. } \\
\text { Elections shrouded in } \\
\text { controversies. }\end{array}$ & $\begin{array}{l}\text { "Stay put" syndrome. } \\
\text { Poor service delivery. } \\
\text { Political corruption. } \\
\text { Failed promises. } \\
\text { Disenchanted } \\
\text { electorate. Rigging. } \\
\text { Electoral and post } \\
\text { election violence. }\end{array}$ \\
\hline Reli & $\begin{array}{l}\text { Veritable platform to } \\
\text { commune with God. } \\
\text { Teach the truth and } \\
\text { guide faithful to } \\
\text { pursue and promote } \\
\text { the truth. Tolerance } \\
\text { of adherents of other } \\
\text { faiths. }\end{array}$ & $\begin{array}{l}\text { Compromised tea- } \\
\text { chings. Less emphasis } \\
\text { on the truth. More } \\
\text { emphasis on material } \\
\text { acquisition, prosperity } \\
\text { and aggressive mem- } \\
\text { bership drive. Into- } \\
\text { lerance of adherents of } \\
\text { other faiths. }\end{array}$ & $\begin{array}{l}\text { Less fear of God. } \\
\text { More focus on profit } \\
\text { making than soul } \\
\text { wining (e.g. religious } \\
\text { organization now } \\
\text { own schools, compa- } \\
\text { nies, transport lines } \\
\text { not for charity but for } \\
\text { profit maximization). } \\
\text { Incessant religions } \\
\text { crisis. }\end{array}$ \\
\hline Econ & $\begin{array}{l}\text { Strong and agrarian- } \\
\text { based. Robust manu- }\end{array}$ & $\begin{array}{l}\text { Weak and oil-rent } \\
\text { based. Weak manufac- }\end{array}$ & $\begin{array}{l}\text { Youth unemploy- } \\
\text { ment, poverty, corru- }\end{array}$ \\
\hline
\end{tabular}




\begin{tabular}{|l|l|l|l|}
\hline facturing sector. & turing sector. Poor & ption, crime. Over- \\
Good conditions of & conditions of service & dependence on white- \\
service. Enhanced w- & especially in the pri- \\
orkers remuneration. & $\begin{array}{l}\text { vate sector. Poor re- } \\
\text { muneration of wor- } \\
\text { foreign goods. Ince- } \\
\text { kers. }\end{array}$ & $\begin{array}{l}\text { ssant industrial ac- } \\
\text { tions. Casualization. }\end{array}$ \\
\hline
\end{tabular}

The transition in Nigeria's traditional values (national character) is further aggravated by the growth of digital technologies. Apparently, cyber-induced modernity has given birth to new forms of crime and criminality in Nigeria, one of which is the yahooboys subculture. Traditional values of faith, hard work, modesty, honesty, brotherliness, temperance, hospitality, tolerance, respect for elders and peace, progress, unity are fast declining. Consequently, greed, materialism, ethnicity, nepotism, individualism, malice, strife, violence, disunity are becoming the order of the day. The perversion of Nigerian's traditional value system has among other things created a group of people with an insatiable quest for power and wealth accumulation. This group by their actions are tending toward returning society to the state of nature where might was right. This group of young adult (the Generation Ys) consider wit as right and use the internet infrastructure to out-wit and defraud their unsuspecting victims of their hard earned monies.

Cyber crime is one of the fastest growing crimes in the twenty-first century world. Studies have shown that cyber crime and particularly online advance fee fraud is on the increase globally. The Twelfth Annual CSI Computer Crime and Security Survey (2007) found that financial fraud overtook virus attacks as the source of the greatest financial loss. Also, Consumer Reports State of the Net (2007) estimated cost of cybercrime to U.S. consumers as more than $\$ 7$ billion, up from the previous year's estimate of $\$ 5.2$ billion. Furthermore, a survey conducted by ITnews Africa in December, 2008 revealed widespread concern over Nigeria's battered image across its borders because of high level and sophisticated incidences of online banking fraud among other felonies (ITnews Africa, 2009). Adeniran (2008) examined the role of the internet in the emergence of the yahooboys sub-culture in Nigeria and found that online fraud was seen as an accepted means of economic sustenance among Nigerian youths particularly those of college age. Quite recently, Iwarimie-Jaja (2013) observed that cyber crime among other crimes of modern Nigeria has battered Nigerian international image, thus causing foreign governments like the US to advise her citizens to take precautionary measures while travelling to Nigeria. Ndubueze (2010) identifies credit and debit card fraud as one of the common online deviant activities of undergraduate students in Nigeria.

The Economic and Financial Crimes Commission (EFCC) has had some successes in arresting and prosecuting some yahoo-yahoo boys in Nigeria. On October 18, 2012, a Lagos High Court sentenced one Liasu, Niass Chiekh 
Assan to three months imprisonment for fraudulently obtaining the sum of $\$ 3,420$ from a Japanese national on the pretext that he was selling him a product. This offense, which violates section 1(3) of the Advance Fee Fraud and other Related Offenses Act No. 14 of 2006, led to the arrest and prosecution of the suspect by the EFCC (Uwujaren 2012). Also, one Bike John Niye was sentenced to one and half year imprisonment by a Lagos High Court for defrauding one Luara Wallman of Indiana United States of America whom he met in a dating site of the sum of $\$ 53,000$ (Uwujare, 2012).

Ayofe \& Oluwaseyifunmitan (2009) identified phishing scam that hit many big Nigerian banks and the use of key logger software to capture online banking details as examples of large scale cyber crimes. The dawn of the 2000s heralded a boom in ICT in Nigeria. Consequently, cyber cafes sprang up across major street and roads of Nigeria, with Lagos having the largest share of the cafes. The increasing dependence of secondary school students on the internet to process examination forms and check their results have also made the cafes a resort of some sort for these young people. Their prolonged stay on the internet has led to a high level of addiction. Many young people now feel compelled to hang out on the internet, some for play and others for various forms of deviance, crime and criminality.

A recent study on cyber crime in Lagos metropolis by Ndubueze (2012) found that younger respondents aged 15 to 34 are more likely to commit cyber crime than the rest of their counterparts. Age was also found to be a good predictor of cyber crime commission. Craze for quick money was one of the factors identified as precipitating cyber crime. Emailing and chatting topped the list of activities of internet users who were mainly younger respondents. Although the study revealed that $90.5 \%$ of the respondents were aware that some people use the internet to carry out unlawful activities, how well they appreciate the extent of their vulnerability to online victimization remains unclear. The celebrated case of Miss Cynthia Osokogu, the daughter of a retired Major-General, who was murdered in cold blood on July 22, 2012 by some yahoo-yahoo boys who posed as her friends, perhaps brings to the fore the plight of thousands of Generation Y Nigerians who have made the internet, and particularly the social media, a relaxation resort of some sort. These young Nigerians are daily exposed to online victimization without knowing it, and sadly, what happened to Miss Osokogu could happen to anyone of them.

Fundamentally, the yahoo-yahoo subculture is an off-shoot of the mainstream culture of the contemporary Nigeria society. This culture idolizes wealth and promotes materialism. It leaves little or no room for morality and ethics. The traditional value orientation that prices a good name over silver and gold seems to be fast declining. Virtues of hard work, integrity, resilience are fast being displaced by "hot cash", "grab-all" and "hit-and-run" syndrome. The emergence of cyber technology with all its promises have further compounded Nigeria's value crisis. Adeniran (2011) perhaps captures the role of Nigeria's value crisis in the emergence of the yahooboys sub-culture thus: 
Money-rather than a good education, scientific discovery, or solid career development - is the yardstick against which people are measured. Hence, society is exposed to youth who have been disillusioned and have not been taught the good virtue of genuine handwork. Such youth have had no trouble immersing themselves in the Internet phenomenon of yahooboyism (p. 5).

Furthermore, because the generation-y were born and bred in the ICT age, they find in the Internet architecture a veritable platform of expression. The anonymity factor has also created a space for the shy ones to connect with their peers. The generation-y under the Internet platform have criss-crossed highly policed borders and have succeeded in building the world of their dreams using the social media as a spring-board. In this world, they interface with unknown persons and shut-out their parents, guardians or siblings from the picture. While some are driven by sheer curiosity and fun, others are driven by malicious and inordinate tendencies. The failed valued system of Nigeria has given birth to a breed of youth whose quest for wealth is inordinate. These youth ambush their unsuspecting victims, mostly expatriates, with a view to fooling and defrauding them.

\section{Values Re-orientation as a Panacea for Cyber Crime Control}

Williams (1970) identified what he considered ten basic American values. These values include: equal opportunity, achievement and success, material comfort, activity and work, practicality and efficiency, progress, science, democracy and enterprise, freedom, racism and group superiority. Schaefer (2003) argues that not all Americans will share all of those values but that the list presents a starting point in defining American national character. Through the mapping of values that defend their national character, apparently, the America society has succeeded in bequeathing the spirit of patriotism and love for their country to its citizens. The average American will think America first and will go all out to be his/her brother's keeper. The government of the United States of America on its part will use every resource at its disposal to protect her citizens, wherever they are across the world.

Unlike the U.S, the Nigerian traditional values are fast declining. The value crisis is fast degenerating. The rut permeates every institution of society and constitutes a brutal assault on the collective conscience of Nigerians. There is therefore a compelling need for Nigeria to revisit and re-enact her core traditional values. This way, it will be dealing with the root causes on cyber crime and particularly the menace of yahooboyism. Every social institution has a crucial role to play and should be actively involved in the proposed value reorientation campaign. The tenor and extent of the roles of social institutions in the value re-orientation crusade are examined below. 


\section{The Role of Governments}

Government business should be treated with the seriousness it deserves. The federal government should declare a national value emergency and organize value summit that will offer stakeholders from all social institutions and the youth the opportunity to re-define Nigeria's national values. The values sodefined and agreed upon at that forum should be made a policy document. The National Orientation Agency (NOA) should print and distribute the document to all institutions of learning and all public offices free of cost. The state and local governments should conduct government business in the most transparent manner, with high level of probity, accountability and zero tolerance for petty and grand corruption.

\section{The Role of Faith Based Organizations (FBOs)}

Since every member of society belongs to a faith based organization, FBOs should therefore be in the vanguard of value re-orientation. Messages disseminated by these organizations should among other things promote values of peace, unity, honesty, tolerance, compassion and hard work. FBOs should preach against the 'money worship syndrome' that is the bane of our society. They should not celebrate questionable characters no matter how fat their donations to these organizations are. The pursuit of economic goals by FBOs should not be at the expense of the pursuit of souls.

\section{The Role of the Family}

By default, every Nigerian belongs to a family and started his or her life journey in a kind of home. Parents should show their children live examples of our true national values. Children learn more from what their parents say and do, than they would from just what they say. In the midst of the struggle for daily living, parents should find time to interact with their children and wards. They should also show more than a passing interest in what their children do and do not do. It is in the hands of parents to lay good foundation for their children. When properly laid, this foundation is more likely to impact on the child's behaviour when peer influence begins to set in. Parents should not leave their children at the mercy of nannies and baby-sitters who sometimes are illequipped and ill-trained to be good role models for these children.

\section{The Role of the School}

The school instils basic societal value in young people. Apart from the family, the school is the next social institution that exerts influence on the child. More often than not, the school offers the child the platform for peer building. Generally, the child's close friend will come from his/her school and most probably from his/her class. Civic education is critical in the child's character moulding and formation. Very crucial is the need to make the child think and love Nigeria. The national values should also be incorporated in the school curriculum at all levels, including the General Study Programme (GSP) taught in institutions of higher learning. 


\section{The Role of Employers of Labour/Corporations}

Employers of labour should be given the national values document free of cost with the advice to adapt it to their mission and vision statements. Appointment and promotion in the public and private sectors should be based on qualification, merit, equity and competence. Corporations should be fair in their dealings with both their employees and customers. Transparency and service should be their guiding principles. They should conduct their businesses with due diligence and in line with global best practices.

\section{The Role of the Media/Nollywood}

The print and electronic media as well as the Nigerian film sector perhaps constitute one of the most powerful platforms for the proposed value reorientation campaign. Newspaper articles, radio and television jingles that promote our national values should be aired daily. Nollywood actors, actresses and directors should do more of films that promote our national values. Films that portray virtues of honesty, tolerance, compassion, peace etc above money should be encouraged.

\section{The Role of the Individual}

Every adult Nigeria should consciously choose to be part of this attitudinal change. Everyone should read the proposed national value document closely and examine him/herself to see where they have deviated. More importantly, everyone should first make conscious efforts to think and act right in all situations, and should not hesitate to ask questions when anyone in their social worlds does otherwise. This way, society can maximize conformity and minimize deviations.

\section{Conclusion}

Nigerian social values have experienced a dramatic transition in the last one decade or so. The traditional values are under a serious threat of extinction. They are fast declining. In their place, a set of values that idolizes wealth is emerging with deep seated impactions for society. The last one decade has seen the creation of the yahooboys deviant sub-culture in Nigeria. The yahooboys subculture constitutes a serious social problem in Nigeria. More disturbing is the fact that this subculture is increasingly becoming sophisticated and complex thereby making it a difficult, though interesting subject of social research.

This paper sees value re-orientation as a key strategy for managing cyber crime in contemporary Nigeria. It calls for an integrated approach in the control of cyber crime and criminality. It argues that every Nigeria as well as the basic social institutions has a critical role to play in the re-definition of Nigeria's national value and character. The federal government of Nigeria needs to make a quick and strategic intervention by mapping out critical 
milestones for an aggressive value-reorientation. Finally, given the growing incidence of crime and criminality particularly Advanced Fee Fraud, and its net effect on Nigeria's image, the call for national value reorientation is perhaps more critical than it was in the pre-yahoo-yahoo era in Nigeria a decade ago.

\section{References}

Adeniran, A.I. 2008. The internet and the emergence of yahooboys sub-culture in Nigeria. International Journal of Cyber Criminology. 2(2):268-381.

Adeniran, A.I. 2011. Cafe culture and heresy of yahooboyism in Nigeria. K. Jaishankar. (ed.). Cyber Criminology: Exploring Internet Crimes and Criminal Behaviour. London: CRC Press. 3-12.

Ayofe, A.N. \& Oluwaseyifunmitan, O. 2009. Towards ameliorating cyber crime and cyber security. (IJCSIS) International Journal of Computer Science and Information Security. 3(1):1-11.

Bohm, R.M. \& Haley, K.N. 2005. Introduction to criminal justice. (4th ed.). Boston: Mc Graw Hill.

Briggs, N.D. 2012. Fulfilling the mandate: Rivers State University of Science \& Technology, Nkpolu-Oroworukwo, Port Harcourt. A Lecture delivered at the 24th Convocation Ceremony of RUST on 3 May, 2012.

Clinnard, M.B. \& Miller, B.F. 1998. Sociology of Deviant Behaviour. (10th ed.). Forthworth: Harcourt Brace.

Consumer Reports State of the Net. 2007. U.S. nationally representative survey of more than 2000 American households conducted by the Consumer Reports National Research Center. Retrieved from http://www.Consumerreports.org/cro/electronics-computers/computers/internet-and-other-services/net-threats-907/overview/0709netov.htm?resultPageIndex=\&resultInde$\mathrm{x} ;=1 \&$ sear-chTerm; $=\% 22$ state $\% 20$ of $\% 20$ the $\% 20$ net.

Friedman, D. \& Hechter, M. 1998. "The Contribution of rational choice theory to Macro sociological research." Sociological Theory. 6:201-218.

Hogan, M.O. 2006. Dictionary of Sociology (1st ed.). New Delhi: Academic (Indian) Publishers.

Horovitz, B. 2012. After generation X, millennials, what should the next generation be? Retrieved September 6, 2013 from http://usatoday30. usatoday.com/money/advertising/story/2012-05-03/naming-the-nextgeneration/54737518/1.

Humtely, R. 2006. The world according to Y: Inside the new adult generation. Allen Unwin.

Internet Crime Compliant Centre - IC3. 2011. Internet Crime Report. January 1, 2010-December 31, 2010 . National White Collar Crime Centre and the Federal Bureau of Investigation. Retrieved June 29, 2013 from, http://www.ic3.gov/media/annualreports.aspx.

Internet Crime Compliant Centre - IC3. 2012. Internet Crime Report. January 1, 2011-December 31, 2011 . National White Collar Crime Centre and the 
Federal Bureau of Investigation. Retrieved June 29, 2013 from, http://www.ic3.gov/media/ annualreports.aspx.

IT news Africa. 2009. Nigerians surveyed on cyber crime. Retrieved November 23, 2009 from: http://www.itnewsafrica.com/?p=1982.

Iwarimie-Jaja, D. 2013. Criminology: The Criminologist's eye in reoccurring crime problem in Nigeria. An inaugural lecture delivered on May 16, 2013 at the University of Port Harcourt.

Jewkesy, Y. 2003. Dot. Cons: crime, deviance and identity on the internet. Cullompton: Willian Press.

Jaishankar, K. 2007. Establishing theory of cyber crimes. International Journal of Cyber Criminology. Retrieved November 27, 2008, from http://www.cybercrime journal.com/Editorialjccjuly.pdf. 1(2):7-9.

Jaishankar, K. 2008. Space transition theory of cyber crime. Schmallagar, F. \& Pittaro, M. (eds.). Crimes of the Internet. Upper Saddle River. NJ: Prentice Hall. 283-301.

Joesph, A.E. 2006. Cyber crime definition. Retrieved October 13, 2009 from http://www.crimeresearch.org/articles/joseph06/.

Marshall, G. 1998. Oxford Dictionary of Sociology. Oxford: Oxford University Press.

Merton, R.K. 1938. Social structure and anomie. American Sociological Review. 3:672-682.

Ndubueze, P.N. 2008. Punishment Philosophies and Penal Paradigms: An Overview. Rivers Journal of the Social Sciences. 6(1 \& 2):11-27.

Ndubueze, P.N. 2010. The Undergraduate's Companion: A Practical Guide to 12 Top Principles of Academic Excellence. Lagos: Nice Press.

Ndubueze, P.N. 2011. "Emerging and continuing trends of deviance subculture and identities among undergraduates in Nigerian tertiary institutions." International Journal of Health and Social Inquiry. 1(1):117-124.

Ndubueze, P.N. 2012. Cyber crime and third party policing in Nigeria: A study of selected cyber cafes in Lagos metropolis. Un-published Ph.D Thesis. University of Nigeria, Nsukka.

Ndubueze, P.N. 2013. Generation Y and online victimization in Nigeria: How vulnerable are younger respondents? A paper delivered at the Second International Conference of the South Asian Society of Criminology and Victimology (SASCV), January 11-13, 2013 at Kanyakumari, Tamil Nadu, India.

Ndubueze, P.N. 2012. Regulatory agencies, third parties and cyber crime control in Nigeria. Bayero Sociologists - A Journal of Sociological Studies. $1(3): 116-135$.

Roberts, L. 2008. Jurisdictional and definitional concerns with computermediated interpersonal crimes: An analysis of cyber stalking. International Journal of Cyber Criminology. 2 (1):271-285. 
Rao, C.N.S. 2012. Sociology: Principles of Sociology with an Introduction to Social Thought. New Delhi: S. Chand.

Rose, J.D. 1983. Deviant Behaviour: Crime, Conflict, and Interest Groups. 4th ed. Chicago: Rand McNally.

Schaefer, R.T. 2003. Sociology. 8th ed. New York: McGraw-Hill.

Swingewood, A. 2003. A Short History of Sociological Thought. London: Macmillian.

Twelfth Annual CSI Computer Crime and Security Survey. 2007. Survey of 494 computer security practitioners in U.S. corporations, government agencies, financial institutions, medical institutions and universities, from http://www.gocsi. com/forms/csi_survey.jhtml, retrieved Mar 31, 2009.

Twenge, J. 2012. Millennials: the greatest generation or the most arcissistic? The Atlantic. Retrieved September 6, 2013 from http://www.theatlantic. com/national/archive /2012/05/ millennials-the-greatest-generation-or-themost-narcissistic/256638/.

Uwujare. 2012. \$3, 420 fradu: court sentences man to 3 months imprisonment. EFCC Media and Public Affairs. Retrieved September 2, 2013 from http://www.efccnigeria.org/efcc/index.php/news/147-3-420-fraud-courtsentences-man-to-3-months-imprisonment.

Uwujare. 2012. \$3, 420 frauds: court sentences man to 3 months imprisonment. EFCC Media and Public Affairs. Retrieved September 2, 2013 from http://www.efccnigeria.org/efcc/index.php/news/84-court-jails-fraudsterover-53-500-romance-scam.

Williams, R.M. Jr. 1970. American Society: A Sociological Interpretation. 3rd ed. New York: Alfred A. Knoph. 